\title{
FREE RADICAL SCAVENGING ACTIVITY AND TOTAL POLYPHENOL CONTENT OF SECURIDACA LONGIPEDUNCULATA ROOTS AND LEAVES EXTRACTS
}

\author{
TITUS CHUKWUEMEKA OBASI ${ }^{1 \#}$, DANIELA BENEDEC ${ }^{2 \#}$, DANIELA HANGANU ${ }^{2}$, ANA- \\ MARIA GHELDIU ${ }^{3}$, LAURIAN VLASE ${ }^{3}$, ILIOARA ONIGA ${ }^{2} *$, CRISTINA PUȘCAȘ ${ }^{4}$, RADU $^{2}$ \\ SILAGHI-DUMITRESCU ${ }^{4 \#}$, RADU OPREAN ${ }^{1}$
}

\author{
${ }^{1}$ Department of Analytical Chemistry and Instrumental Analysis, "Iuliu Hațieganu” University of Medicine and Pharmacy, \\ Cluj-Napoca, Romania \\ ${ }^{2}$ Department of Pharmacognosy, "Iuliu Hațieganu” University of Medicine and Pharmacy, Cluj-Napoca, Romania \\ ${ }^{3}$ Department of Pharmaceutical Technology and Biopharmacy, "Iuliu Hațieganu” University of Medicine and Pharmacy, \\ Cluj-Napoca, Romania \\ ${ }^{4}$ Department of Chemistry and Chemical Engineering, "Babeş-Bolyai” University, Cluj-Napoca, Romania
}

*corresponding author: ilioara4@yahoo.com

${ }^{\#}$ These authors contributed equally to the work.

\begin{abstract}
Securidaca longipedunculata Fresen. is a widely used medicinal plant in most of the African countries. This paper aims to compare the polyphenolic composition and antioxidant activity of some extracts obtained from S. longipedunculata roots and leaves in different solvents: ethanol (E), petroleum ether (PE), ethyl acetate (EtOAc), and water (W). Polyphenols were analysed by spectrophotometric and chromatographic methods. Evaluation of antioxidant activity was performed by several in vitro methods (DPPH bleaching, FRAP, nitrite-induced auto-oxidation of haemoglobin, inhibition of lipid peroxidation catalysed by cytochrome C). Our results revealed that the leaves were abundant in phenolic principles than the roots and the EtOAc was the appropriate solvent for their extraction. The EtOAc extracts exhibited the best antioxidant potential. Several polyphenols were determined in the leaves extracts for the first time: hyperoside, isoquercitrin, rutin, $p$-coumaric acid.
\end{abstract}

\section{Rezumat}

Securidaca longipedunculata Fresen. este o plantă medicinală utilizată pe scară largă în majoritatea țărilor africane. Această lucrare își propune să compare compoziția polifenolică și activitatea antioxidantă a unor extracte obținute din rădăcini și frunze de S. longipedunculata în diferiți solvenți: etanol (E), eter de petrol (PE), acetat de etil (EtOAc) şi apă (W). Polifenolii au fost analizați prin metode spectrofotometrice și cromatografice. Evaluarea activității antioxidante a fost efectuată prin mai multe metode in vitro (DPPH, FRAP, autooxidarea hemoglobinei indusă de nitriți, inhibarea peroxidării lipidice catalizată de citocromul $c$ ). Rezultatele noastre au arătat că frunzele au fost mai bogate în principii fenolice decât rădăcinile, iar acetatul de etil a fost cel mai bun solvent pentru extracție. Extractele în EtOAc au prezentat cel mai bun potențial antioxidant. Polifenolii de tip hiperozidă, izoquercitrină, rutozidă, acid p-cumaric au fost determinați pentru prima dată în extractele obținute din frunze.

Keywords: Securidaca longipedunculata; roots and leaves extracts

\section{Introduction}

Securidaca longipedunculata Fresen. (Violet tree) belongs to the Polygalaceae family, being widely used in traditional African medicine as a supply of local health care [13]. According to scientific reports, this species has relevant applications in ethno-medicine, with multiple indications for human diseases (asthma, hepatic infection, coughs, epilepsy, malaria, tuberculosis, constipation, headache, rheumatism, stomach ache) $[5,6,13]$. Numerous studies have reported that roots extracts have antimicrobial, antioxidant, antidiabetic, anticonvulsant, anti-inflammatory, antimalarial, insecticidal, pesticidal properties $[12,15,16,19]$. As far as we know, few investigations have been reported on leaves extracts, although this medicinal plant is widely used $[1,9,10]$. So, the purpose of this study was to compare the chemical composition of different extracts obtained by leaves and roots of $S$. longipedunculata species, as well as to investigate their antioxidant potential, for better characterization and exploitation of these plant materials.

\section{Materials and Methods}

Plant material and extraction procedure. Freshly collected S. longipedunculata (S) leaves and roots were dissected into small sizes and dried at room temperature. The voucher specimen number according to the herbarium (Ethnobotany unit) of the Department 
FARMACIA, 2020, Vol. 68, 1

of Medicinal Plants Research and Traditional Medicine, National Institute for Pharmaceutical Research and Development (NIPRD), Idu, Abuja, Nigeria is NIPRD/ $\mathrm{H} / 6576$. The dried materials were powdered using electric blender (Bosch). The powdered plant materials: roots (radix, R, $30 \mathrm{~g}$ ) and leaves (folium, F, $15 \mathrm{~g}$ ) were extracted two times with $95 \%$ ethanol $(150 \mathrm{~mL} \times 2)$ under reflux for one hour each time, followed by filtration, combination and evaporation in vacuum to give the $95 \%$ ethanol dry extracts (SR1: $1.184 \mathrm{~g}$ and SF1: $4.216 \mathrm{~g})$. The dried ethanolic extracts (0.824 g SR1 and $3.173 \mathrm{~g} \mathrm{SF} 1$ dry extract) were suspended in water $(100 \mathrm{~mL})$ and transferred into the separatory funnel, then were sequentially extracted with petroleum ether (PE,100 mL x 3) and ethyl acetate (EtOAc, $400 \mathrm{~mL}$ x 3) to give petroleum ether extracts (SR2: $0.144 \mathrm{~g}$ and FS2: $0.216 \mathrm{~g}$ dry extract), ethyl acetate extracts (SR3: $0.264 \mathrm{~g}$ and SF3: $0.455 \mathrm{~g}$ dry extract), and water extracts (SR4: $0.413 \mathrm{~g}$ and SF4: $2.502 \mathrm{~g}$ dry extract) after removing the solvent in vacuum [11]. The solutions used for the analysis were obtained by dissolving the dried extracts in methanol.

Chemicals, quantitative analysis and HPLC chromatographic conditions. Chemicals were obtained from Merck, Alfa-Aesar and Roth (Germany).

Determination of total polyphenolic content (TPC). The TPC of the extracts was determined by slightly modified Folin-Ciocâlteu method [20]. Each extract of $S$. longipedunculata roots and leaves was mixed with Folin- Ciocâlteu reagent and sodium carbonate solution. Standard calibration curve was made with gallic acid plotted at 0.02, 0.04, 0.06, 0.08, and 0.10 $\mathrm{mg} / \mathrm{mL}$ and prepared in methanol: water $(50: 50, \mathrm{v} / \mathrm{v})$. TPC values were determined using the equation and slope generated from the calibration curve $\left(R^{2}=0.999\right)$ and the results were expressed as $\mathrm{mg}$ of gallic acid equivalent (GAE)/g dry extract $[2,17,20]$.

DPPH radical-scavenging activity. Free radical scavenging activity of $S$. longipedunculata extracts was measured by DPPH method. The DPPH solution $(0.1 \mathrm{~g} / \mathrm{L})$ in methanol was prepared and $2.0 \mathrm{~mL}$ was added to $2.0 \mathrm{~mL}$ of extract (or standard) at different concentrations (SR1: 37.5 - 131.25 $\mu \mathrm{g} / \mathrm{mL}$; SR2: 28.5 $228 \mu \mathrm{g} / \mathrm{mL}$; SR3: 19.8 - $69.3 \mu \mathrm{g} / \mathrm{mL}$; SR4: 206.5 $619.5 \mu \mathrm{g} / \mathrm{mL}$; SF1: 62.5 - $218.75 \mu \mathrm{g} / \mathrm{mL}$; SF2: 108 432; SF3 $\mu \mathrm{g} / \mathrm{mL}: 8.53$ - $59.71 \mu \mathrm{g} / \mathrm{mL}$; SF4: 62.55 $218.92 \mu \mathrm{g} / \mathrm{mL}$ ). The absorbance values were recorded at $517 \mathrm{~nm}$. The antioxidant ability of natural compounds is based on quenching of stable coloured radical $\mathrm{DPPH}$. The $\mathrm{IC}_{50}$ values for $\mathrm{DPPH}$ radical scavenging ability were represented by the concentration at which the samples exhibited 50\% inhibition of the DPPH free radical. The \% DPPH inhibition was plotted against Log dose (concentration) to obtain the curve and the $\mathrm{IC}_{50}[4,7]$.

FRAP Assay. The antioxidant capacity of the extracts was estimated by the spectrophotometrically ferric reducing/antioxidant power (FRAP) assay following the procedure of Benzie and Strain [3]. The FRAP method relies on the colour changing of a complex with $\mathrm{Fe}^{+3}$ ion, the TPTZ (2,4,6 tripyridyl-S-triazine) radical (colourless complex), by the reduction of the $\mathrm{Fe}^{3+}$ form of iron to $\mathrm{Fe}^{+2}$-tri-pyridyltriazine (blue coloured complex), which is due to the action of the electron donation from antioxidants. Trolox was used as a reference. The colour change was correlated with the antioxidant capacity by measuring the absorbance at $450 \mathrm{~nm}$. Using a calibration curve $\left(\mathrm{R}^{2}=0.992\right)$, the results were converted to $\mu \mathrm{M}$ Trolox equivalents/g dry extract.

Nitrite-induced auto-oxidation of haemoglobin. The nitrite-induced auto-oxidation of haemoglobin $(\mathrm{Hb})$ was studied at $580 \mathrm{~nm}$, the wavelength where the transformation of haemoglobin from oxyhaemoglobin (oxy- $\mathrm{Hb}$ ) to methaemoglobin (met-Hb) can be observed. Thus, $40 \mu \mathrm{M}$ oxy-Hb were mixed with $166 \mu \mathrm{M}$ nitrite in the presence of extracts. The obtained curve was fitted with a sigmoidal equation and the inflection time $\left(\mathrm{t}_{\mathrm{i}}\right)$ was calculated using Origin 8 . The results are expressed in mg CAE (chlorogenic acid)/g material plant, using a calibration curve with a $\mathrm{R}^{2}$ of 0.99 [8]. Inhibition of lipid peroxidation catalysed by cytochrome $C$. Liposomes were obtained by sonication of $5 \mathrm{mg} / \mathrm{mL}$ soy lecithin, in phosphate $10 \mathrm{mM}, \mathrm{pH}$ 7. The reaction was catalysed by $2 \mu \mathrm{M}$ cytochrome $\mathrm{C}$ in the presence of extracts $(8.3 \mu \mathrm{g} / \mathrm{mL})$ and was monitored in time at $235 \mathrm{~nm}$ [14].

HPLC-MS methods. The analysis of phenolic compounds previously described was conducted with an Agilent 1100 HPLC Series system equipped with a degasser and quaternary gradient pump, a model G1311A diode array detector system, a Zorbax SB-C18 reverse-phase analytical column [2, 4, 7]. All compounds were identified by comparison of retention times and the MS spectra with those of the standards, using the same parameters and chromatographic conditions. In order to identify polyphenols such as epicatechin, catechin, siringic, gallic, protocatechuic and vanillic acids, another HPLC-MS method previously described was used $[4,7]$. The polyphenol compounds were determined on their peak areas and compared to a calibration curve of their six corresponding standards [4, 7]. The results were expressed as $\mathrm{mg} / \mathrm{g}$ dry extract.

\section{Results and Discussion}

The polyphenolic contents were analysed in all extracts obtained from roots and leaves of $S$. longipedunculata (Table I). The ethyl acetate extracts from roots (SR3) and leaves (SF3) contained the largest amounts of polyphenols with close values (147.52 and 145.32 $\mathrm{mg} / \mathrm{g}$, respectively). The concentration of polyphenols in the different roots extracts was influenced by the solvent and varied in the following order: SR3-AcOEt $(147.52 \mathrm{mg} / \mathrm{g})>$ SR1-E $(76.75 \mathrm{mg} / \mathrm{g})>\mathrm{SR} 4-\mathrm{W}(45.09$ $\mathrm{mg} / \mathrm{g})>$ SR2-PE (20.61 mg/g). Previously, it was 
shown that the water-methanol extracts from roots of the Nigerian species contained smaller amounts of polyphenols [13]. Regarding the polyphenolic content of the leaves (Table I), the EtOAc extract (SF3) was the richest $(145.32 \mathrm{mg} / \mathrm{g})$, followed in order by the extracts: SF2 - PE (56.71 mg/g), SF1 - E (41.20 mg/g), SF4 - W (28.42 mg/g). Previous analyses were performed on chloroformic and methanolic extracts, revealing different values (below $30 \mathrm{mg} / \mathrm{g}$ in the chloroformic extract and 75 - $100 \mathrm{mg} \mathrm{GAE} / \mathrm{g}$ in the methanolic extract) [9].

The antioxidant effect of the extracts was evaluated in vitro by the DPPH and FRAP methods. The EtOAc extracts (SR3 and SF3) showed the best scavenging ability on DPPH radical compared to the other extracts. The SF3 extract demonstrated a very good antioxidant activity, with the lowest $\mathrm{IC}_{50}$ value $(31.95 \mu \mathrm{g} / \mathrm{mL})$, comparable to that of Trolox. The SF3 and SR3 extracts also demonstrated a strong ferric ion reducing capacity $(682.14 \mu \mathrm{M} \mathrm{TE} / \mathrm{g}$, and $465.09 \mu \mathrm{M} \mathrm{TE} / \mathrm{g}$, respectively), in good agreement with the polyphenolic content. Our findings seem to be supported by several previous studies [13]. Thus, S. longipedunculata species, especially the leaves extract in AcOEt, could be an important source of antioxidant phenolic compounds, capable to neutralize the reactive oxygen species and to protect against the damages of the oxidative stress.

Table I

Total polyphenol content and antioxidant activity of $S$. longipedunculatae radix and folium dry extracts

\begin{tabular}{|c|c|c|c|}
\hline Samples & TPC (mg GAE/g dry extract) & DPPH IC $_{50}(\mu \mathrm{g} / \mathrm{mL}$ dry extract $)$ & FRAP $(\mu M$ TE/g dry extract $)$ \\
\hline SR1 (95\% ethanol) & $76.75 \pm 1.25$ & $116.99 \pm 5.01$ & $288.80 \pm 7.20$ \\
\hline SR2 (PE) & $20.61 \pm 0.38$ & $>200$ & $173.81 \pm 3.19$ \\
\hline SR 3 (EtOAc) & $147.52 \pm 2.47$ & $60.12 \pm 2.87$ & $465.09 \pm 8.91$ \\
\hline SR 4 (water) & $45.09 \pm 0.40$ & $>200$ & $88.47 \pm 1.53$ \\
\hline SF1 (95\% ethanol) & $41.20 \pm 0.39$ & $119.27 \pm 2.72$ & $154.35 \pm 5.65$ \\
\hline SF 2 (PE) & $56.71 \pm 1.28$ & $>200$ & $101.08 \pm 3.92$ \\
\hline SF 3 (EtOAc) & $145.32 \pm 2.67$ & $31.95 \pm 1.04$ & $682.14 \pm 17.86$ \\
\hline SF 4 (water) & $28.42 \pm 0.57$ & $163.75 \pm 2.24$ & $96.35 \pm 2.65$ \\
\hline Trolox & - & $11.20 \pm 0.09$ & - \\
\hline
\end{tabular}

GAE: gallic acid equivalents; TE: Trolox equivalents.

Nitrite can induce the auto-oxidation of $\mathrm{Hb}$ according to the mechanism previously described [8] and the presence of antioxidants can inhibit this reaction. Figure 1 illustrates the inhibition of oxidation of $\mathrm{Hb}$ by nitrite in the presence of the best-performing extracts from roots (RS3) and leaves (SF3) of $S$. longipendunculata. Both extracts have a good capacity to inhibit the oxidation of $\mathrm{Hb}$ by nitrite, twice as much in the roots extract compared to the leaves extract. This ratio of reactivity matches the one seen in DPPH assay measurements (Table I) but not in total phenolic content (equal values between the two extracts) or FRAP (reverse order).

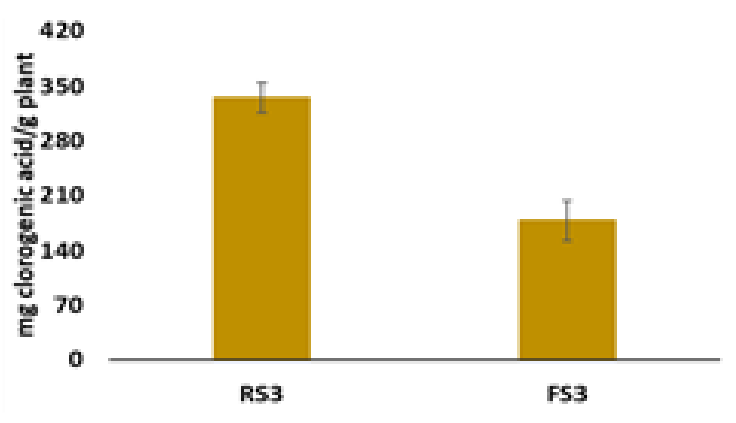

Figure 1.

The inhibition of the oxidation of haemoglobin by nitrite in the presence of $S$. longipendunculata extracts. The inflection time $\left(\mathrm{t}_{\mathrm{i}}\right)$ is converted in $\mathrm{mg} \mathrm{CAE} / \mathrm{g}$ plant $(\mathrm{Hb}-20 \mu \mathrm{M}$; nitrite $-166 \mu \mathrm{M}$; phosphate $\mathrm{pH} 7)$
Inhibition of lipid peroxidation catalyzed by cytochrome $C$. Both the SR3 and SF3 extracts (from roots and leaves) inhibit the lipid peroxidation catalysed by cytochrome $\mathrm{C}$ at very low concentration $(1.66 \mu \mathrm{g} / \mathrm{ml})$. In this experiment, the antioxidant capacity is directly correlated with the length of the lag phase. The RS3 shows the longest lag phase, suggesting the best antioxidant capacity - in good agreement with the data from the nitrite-induced auto-oxidation (Figure 2).

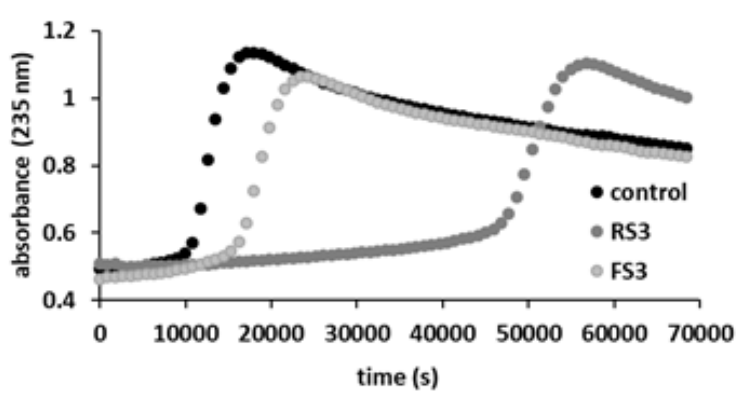

Figure 2.

Time course for the oxidation of liposomes catalysed by cytochrome $\mathrm{C}$ in the presence of the $S$. longipedunculata extracts

(cytochrome $\mathrm{C}-2 \mu \mathrm{M}$; liposomes $-0.5 \mathrm{~g} / \mathrm{mL}$; extracts $-1.66 \mu \mathrm{g} / \mathrm{mL}$; phosphate $-10 \mathrm{mM} ; \mathrm{pH} 7$ )

HPLC-MS analysis

The identification and quantification of flavonoids and phenolic acids from leaves and roots of $S$. longipedunculata were performed by the HPLC-MS 
FARMACIA, 2020, Vol. 68, 1

methods (Tables II and III). The eight different extracts were analysed using the same chromatographic conditions as those for standard substances. Identification was based on their retention times and UV and MS spectra as compared to standards. Quantification was performed using an external standard method, with 27 standard phenolic compounds $[2,4,7]$.

Table II

Phenolic compounds identified by the HPLC method in the S. longipedunculata roots extracts

\begin{tabular}{|l|c|c|c|c|c|}
\hline \multirow{2}{*}{ Phenolic compounds } & \multirow{2}{*}{ Retention time, min } & \multicolumn{4}{c|}{ Concentrations (mg/g dry extract) } \\
\cline { 3 - 6 } & & SR1-E & SR2-PE & SR3-AcOEt & SR4-W \\
\hline Protocatechuic acid & $2.8 \pm 0.06$ & $0.04 \pm 0.01$ & - & $0.14 \pm 0.04$ & - \\
\hline Gentisic acid & $3.69 \pm 0.04$ & - & - & $<0.02$ & - \\
\hline Chlorogenic acid & $6.43 \pm 0.05$ & $<0.02$ & - & $<0.02$ & $<0.02$ \\
\hline Vanillic acid & $6.7 \pm 0.06$ & $0.46 \pm 0.03$ & - & $2.09 \pm 0.10$ & - \\
\hline Syringic acid & $8.4 \pm 0.08$ & $0.32 \pm 0.06$ & - & $1.28 \pm 0.06$ & - \\
\hline Ferulic acid & $12.8 \pm 0.10$ & $<0.02$ & - & $0.07 \pm 0.01$ & - \\
\hline Rutin & $20.76 \pm 0.15$ & - & - & - & $0.03 \pm 0.02$ \\
\hline
\end{tabular}

Table III

Phenolic compounds identified by the HPLC method in the $S$. longipedunculata leaves extracts

\begin{tabular}{|l|c|c|c|c|c|}
\hline \multirow{2}{*}{ Phenolic compounds } & \multirow{2}{*}{ Retention time, min } & \multicolumn{3}{|c|}{ Concentrations (mg/g dry extract) } \\
\cline { 3 - 6 } & & SF1-E & SF2-PE & SF3-AcOEt & SF4-W \\
\hline Protocatechuic acid & $2.8 \pm 0.06$ & $0.04 \pm 0.01$ & - & $0.54 \pm 0.15$ & - \\
\hline Gentisic acid & $3.69 \pm 0.04$ & - & - & - & - \\
\hline Caffeic acid & $5.60 \pm 0.04$ & $0.07 \pm 0.02$ & - & $<0.02$ & - \\
\hline Chlorogenic acid & $6.43 \pm 0.05$ & - & - & $0.56 \pm 0.13$ & - \\
\hline Vanillic acid & $6.7 \pm 0.06$ & - & - & $0.16 \pm 0.02$ & - \\
\hline Syringic acid & $8.4 \pm 0.08$ & - & - & $0.07 \pm 0.01$ & - \\
\hline p-Coumaric acid & $9.48 \pm 0.08$ & $0.47 \pm 0.02$ & $0.15 \pm 0.03$ & $3.62 \pm 0.27$ & - \\
\hline Ferulic acid & $12.8 \pm 0.10$ & $0.21 \pm 0.07$ & $0.12 \pm 0.03$ & $1.38 \pm 0.11$ & - \\
\hline Hyperoside & $18.60 \pm 0.12$ & $3.36 \pm 0.23$ & $0.54 \pm 0.15$ & $18.28 \pm 1.72$ & $<0.02$ \\
\hline Isoquercitrin & $20.29 \pm 0.10$ & $1.68 \pm 0.11$ & $0.33 \pm 0.06$ & $16.10 \pm 1.39$ & $<0.02$ \\
\hline Rutin & $20.76 \pm 0.15$ & $2.74 \pm 0.15$ & $0.23 \pm 0.02$ & $4.92 \pm 1.07$ & $3.41 \pm 0.13$ \\
\hline Quercitrin & $23.64 \pm 0.13$ & - & - & $<0.02$ & - \\
\hline Quercetin & $27.55 \pm 0.15$ & $0.20 \pm 0.09$ & $0.16 \pm 0.02$ & $0.79 \pm 0.07$ & - \\
\hline
\end{tabular}

A total of seven compounds were found in the extracts of $S$. longipedunculata roots (Table II). The EtOAc (SR3) and ethanolic (SR1) extracts were found to have a large amount of phenolic principles compared to other extracts. Vanillic, syringic and protocatechuic acids were determined for the first time, and the EtOAc was the most appropriate solvent for their extraction. Other authors reported the presence of some polyphenolic compounds in S. longipedunculata, such as: chlorogenic acid, caffeic acid, $p$-coumaric acid, rutin, quercetin [13]. Regarding the analysis of the four leaves extracts, 12 polyphenolic compounds were determined for the first time (Table III). The richest was the EtOAc extract (SF3), followed by the ethanolic extract (SF1). The SF3 extract contained large amounts of flavonoids: hyperoside $(18.28 \mathrm{mg} / \mathrm{g})$, isoquercitrin $(16.10 \mathrm{mg} / \mathrm{g})$ and rutin $(4.92 \mathrm{mg} / \mathrm{g})$, as well as phenolic acids: $p$-coumaric acid $(3.62 \mathrm{mg} / \mathrm{g})$ and ferulic acid $(1.38 \mathrm{mg} / \mathrm{g})$. The solid-liquid and liquid-liquid extraction methods are the most commonly used for the polyphenols analysis and the yield and rate of polyphenolic extraction depends on the solvent characteristics. Various polarities of solvents are able to extract various combinations of phenolic compounds. Obtaining new fractions from the initial extract, using different solvent, emphasized the presence of new compounds, which were not in the limit of detection in the initial extract. The fractions are more concentrated in those compounds, so they could be identified by the used HPLC method. Thus, the EtOAc extracts of S. longipedunculata leaves and roots were the richest in flavonoids and phenolic acids, which could be the main bioactive compounds responsible for the very good antioxidant capacity of these extracts.

\section{Conclusions}

In the present study, different extracts (in ethanol $95 \%$, petroleum ether, ethyl acetate and water) from roots and leaves of $S$. longipedunculata were studied in terms of polyphenolic compounds and antioxidant activity. Our results highlight that ethyl acetate extracts from leaves showed very good antioxidant properties as well as high content of polyphenolic compounds, of which some flavonoids: hyperoside, isoquercitrin and rutin, as well as $p$-coumaric acid and ferulic acid were identified. These findings support some of the many traditional uses of this African medicinal plant, based on the antioxidant capacity of the polyphenolic compounds of the leaves and, in addition, 
this raw material could be considered a potential source of new drugs.

\section{Acknowledgement}

The financial support from "Iuliu Hațieganu" University of Medicine and Pharmacy, Cluj-Napoca, Romania is kindly acknowledged for my $\mathrm{PhD}$ research (Obasi T., number 5200/70/01.03.2017).

\section{Conflict of interest}

The authors declare no conflict of interest.

\section{References}

1. Abonyi O, Uzoegwu PN, Ezugwu AL, Uroko RI, Ani CC, Onyemuche TN, Anigbogu JU, In vitro antioxidant profile of methanol leaf extract of Securidaca longepedunculata. IOSR J Dent Medic Sci., 2014; 13(11): 75-81.

2. Andriamadio JH, Rasoanaivo LH, Benedec D, Vlase L, Gheldiu AM, Duma M, Toiu A, Raharisololalao A, Oniga I, HPLC/MS analysis of polyphenols, antioxidant and antimicrobial activities of Artabotrys hildebrandtii O. Hffm. extracts. Nat Prod Res., 2015; 29(23): 2188-2196.

3. Benzie IFF, Strain JJ, The ferric reducing ability of plasma (FRAP) as a measure of "Antioxidant Power": The FRAP Assay. Anal Biochem., 1996; 239(1): 70-76.

4. Epure A, Oniga I, Benedec D, Hanganu D, Gheldiu AM, Toiu A, Vlase L. Chemical analysis and antioxidant activity of some Rooibos tea products. Farmacia, 2019; 67(6): 963-966.

5. Gabriel EI, Ebere IT, Onyema EI, Adaku ET, Uchenna EU, Nwabuisi OC, Otah AA, Evaluation of the methanol root extract of Securidaca longipedunculata for antitrypanosomal activity in vitro and in vivo. Thai J Pharm Sci., 2015; 39(4): 155-159.

6. Gbadamosi I, Oluwatosin Adeyi A, Agbatutu A, Anti-inflammatory activity and toxicological effect of Securidaca longepedunculata (Fresen.) root bark extract in albino rats. Appl Med Res., 2017; 3(1): 5-11.

7. Hanganu D, Olah N, Pop C, Vlase L, Oniga I, Ciocarlan N, Matei A, Pușcaș C, Silaghi-Dumitrescu R, Benedec D. Evaluation of polyphenolic profile and antioxidant activity for some Salvia species. Farmacia, 2019; 67(5): 801-805.

8. Hathazi D, Scurtu F, Bischin C, Mot AC, Attia A, Kongsted J, Silaghi Dumitrescu R, The reaction of oxy hemoglobin with nitrite: mechanism, antioxidantmodulated effect, and implications for blood substitute evaluation. Molecules, 2018; 23(2): E350: 1-16.

9. Issa K, Moussa C, Orokia T, Souleymane S, Latifou L, Martin K, Comparative study of leaves and root bark from Securidaca longepedunculata Fresen (Polygalaceae): Phytochemistry and antiplasmodial activity. Pharma Innov J., 2018; 7(10): 178-184.

10. Junaid SA, Abubakar, A; Ofodile, AC; Olabode, AO; Echeonwu, GON; Okwori, AEJ; Adetunji, JA, Evaluation of Securidaca longipenduculata leaf and root extracts for antimicrobial activities. Afr J Microbiol Res., 2008; 2(12): 322-325.

11. Long X, Zeng X, Yan H, Xu M, Zeng Q, Xu C, Xu Q, Zhang LY, Flavonoids composition and antioxidant potential assessment of extracts from Gannanzao navel orange (Citrus sinensis Osbeck Cv. Gannanzao) peel. Nat Prod Res., 2019; 3: 1-5.

12. Mitaine-Offer AC, Pénez N, Miyamoto T, Delaude C, Mirjolet JF, Duchamp O, Lacaille-Duboi MA. Acylated triterpene saponins from the roots of Securidaca longepedunculata. Phytochemistry, 2010; 71(1): 90-94.

13. Mongalo NI, McGaw LJ, Finnie JF, Staden JV, Securidaca longipedunculata Fresen (Polygalaceae): a review of its ethnomedicinal uses phytochemistry, pharmacological properties and toxicology. J Ethnopharmacol., 2015; 165: 215-26.

14. Mot AC, Bischin C, Muresan B, Parvu M, Damian G, Vlase L, Silaghi-Dumitrescu R, Antioxidant activity evaluation by physiologically relevant assays based on haemoglobin peroxidase activity and cytochrome Cinduced oxidation of liposomes. Nat Prod Res., 2016; 30(11): 1315-1319.

15. Obasi TC, Braicu C, Iacob BC, Bodoki E, Jurj A, Raduly L, Oniga I, Berindan-Neagoe I, Oprean R, Securidaca-saponins are natural inhibitors of AKT, MCL-1, and BCL2L1 in cervical cancer cells. Cancer Manag Res., 2018; 10: 5709-5724.

16. Okoli CO, Akah PA, Ezugworie U, Anti-inflammatory activity of extracts of root barks Securidaca longipedunculata Fres (Polygalaceae). Afr J Trad CAM., 2005; 2(3): 54-63.

17. Oniga I, Toiu A, Hanganu D, Vlase L, Duda M, Benedec D, Influence of fertilizer treatment on the chemical composition of some Calendula officinalis varieties cultivated in Romania. Farmacia, 2018; 66(6): 995-998.

18. Simirgiotis MJ, Antioxidant capacity and HPLC-DADMS profiling of Chilean peumo (Cryptocarya alba) fruits and comparison with German peumo (Crataegus monogyna) from Southern Chile. Molecules, 2013; 18(2): 2061-2080.

19. Stevenson PC, Dayarathna TK, Belmain SR, Veitch NC, Bisdesmosidic saponins from Securidaca longepedunculata roots: evaluation of deterrency and toxicity to Coleopteran storage pests. J Agric Food Chem., 2009; 57(19): 8860-8867.

20. $\mathrm{xxx}$ - European Pharmacopoeia, $8^{\text {th }}$ edition, Council of Europe, 2014. 